\title{
Distribusi dan keanekaragaman jenis makroalga pada ekosistem lamun dan terumbu karang di pantai Desa Haya, Kabupaten Maluku Tengah, Provinsi Maluku
}

\author{
Distribution and diversity of seaweed in seagrass ecosystems and coral reef in the coast \\ of the Haya Village, Central Maluku Regency, Maluku Province
}

\author{
Karel Markus Melsasail*, Umar Namakule
}

Program Studi Pendidikan Biologi, Fakultas Pendidikan Matematika dan Ilmu Pengetahuan Alam, STKIP Gotong Royong Masohi, Jalan Trans Seram Belakang Negeri Haruru Masohi, Indonesia - 97514

*Email: karel.melsasail@yahoo.com

Diterima 9 Agustus 2020

Disetujui 22 November 2020

\section{INTISARI}

Haya merupakan salah satu desa di Kabupaten Maluku Tengah yang memiliki keanekaragaman jenis makroalga tersebar pada berbagai habitat dan belum teridentifikasi jenis serta sebarannya pada ekosistem lamun dan terumbu karang. Selain itu juga, keberadaan makroalga terancam oleh berbagai macam aktifitas masyarakat seperti pembuangan sampah dan limbah rumah tangga ke pantai, serta aktifitas nelayan menggunakan perahu yang merusak habitat makroalga. Dengan demikian peneliti merasa sangat perlu untuk melaksanakan penelitian ini. Tujuan dari penelitian ini untuk mengetahui distribusi dan keanekaragaman jenis makroalga pada ekosistem lamun dan terumbu karang di pantai desa Haya. Pengumpulan data dilakukan dengan metode transek liniear kuadrat. Transek yang digunakan sebanyak 5 buah dengan kuadrat berukuran 1x1 meter sebanyak 10 buah, serta didukung dengan pengukuran parameter fisika kima perairan seperti suhu menggunakan termometer, kuat arus menggunakan bola arus, kedalaman menggunakan tongkat berskala, salinitas menggunakan refaktometer, dan $\mathrm{pH}$ menggunakan $\mathrm{pH}$ meter. Jenis makroalga yang ditemukan di pantai Desa Haya sebanyak 12 jenis, 5 jenis pada ekosistem lamun dan 7 jenis pada terumbu karang. Distribusi makroalga pada ekosistem lamun dengan cara melekat pada substrat pasir dan lumpur, sedangkan pada terumbu karang dengan cara melekat dan menancap pada batu karang di rataan terumbu. Nilai keanekaragaman jenis makroalga pada ekosistem lamun tergolong rendah $(1,381)$, sedangkan pada terumbu karang tergolong sedang $(2,806)$. Kondisi faktor fisika-kimia perairan berupa suhu $\left(29,2^{\circ} \mathrm{C}\right)$, kuat arus $(23,8 \mathrm{~cm} /$ detik $)$, kedalaman $(124 \mathrm{~cm})$, dan salinitas air laut $(32,9 \mathrm{ppt})$ masih berada dalam kisaran yang baik untuk pertumbuhan makroalga, sedangkan derajat keasaman $(\mathrm{pH})$ air laut $(6,07)$ berada dalam kisaran yang tidak baik bagi perumbuhan makroalga.

Kata kunci: habitat, metode transek, faktor fisika kimia

\begin{abstract}
Haya is one of the villages in Central Maluku Regency which has a diversity of seaweed species spread over various habitats and the species and distribution of seagrass and coral reef ecosystems have not been identified. In addition, the existence of seaweed is also threatened by various kinds of community activities, such as dumping garbage and household waste to the beach, as well as fishing activities using boats that destroy macroalgae habitat. Thus the researcher felt it was very necessary to carry out this research. The purpose of this study was to determine the distribution and diversity of seaweed species in seagrass and coral reef ecosystems on the coast of Haya village. The data was collected by using quadratic linear transect
\end{abstract}


method. There are 5 transects used with squares measuring $1 \mathrm{x} 1$ meter as many as 10 pieces, and supported by measurement of water chemistry parameters such as temperature using a thermometer, current strength using a flow ball, depth using a scale stick, salinity using a refactometer, and $\mathrm{pH}$ using a $\mathrm{pH}$ meter. There are 12 species of seaweed found on the coast of Haya village, 5 species in the seagrass ecosystem and 7 species on coral reefs. The distribution of seaweed in seagrass ecosystems is by attaching to the substrate of sand and mud, while on coral reefs by attaching and sticking to rocks on the reef flats. The value of seaweed diversity in the seagrass ecosystem is low (1.381), while the coral reefs are classified as medium (2.806). The condition of the physic-chemical factors of the waters in the form of temperature $\left(29.2^{\circ} \mathrm{C}\right)$, current strength $(23.8 \mathrm{~cm} / \mathrm{sec})$, depth $(124 \mathrm{~cm})$, and sea water salinity $(32.9 \mathrm{ppt})$ are still in a good range for seaweed growth, meanwhile the degree of acidity $(\mathrm{pH})(6.07)$ is in a range that is not good for seaweed growth.

\section{Keywords: habitat, transect method, Fisic and chemist factor}

\section{PENDAHULUAN}

Makroalga merupakan salah satu keanekaragaman hayati yang melimpah di perairan Indonesia yaitu sekitar $86 \%$ dari total biota laut (Ayhuan dkk., 2017; Nurmiyati, 2013). Makroalga merupakan tumbuhan tingkat rendah yang dapat berfotosintesis (Melsasail et al., 2018; Soegiarto dkk., 2011). Keseluruhan tubuh makroalga disebut thallus yang terdiri dari blade, stipe, dan holdfast (Melsasail et al., 2018). Makroalga terbagi dalam tiga kelas yaitu Chlorophyceae, Phaeophyceae, dan Rhodophyceae yang memiliki banyak jenis (Soegiarto dkk., 2011). Distribusi makroalga sangat dipengaruhi oleh faktor lingkungan dan habitat (Krupek \& Branco, 2012; Litaay, 2014). Melalui distribusi, dapat diketahui daerah yang menjadi tempat hidup dan bagaimana cara makroalga hidup di tempat tersebut. Apabila faktor lingkungan dan habitatnya baik, maka distribusi dan keanekaragaman jenis makroalga juga akan baik (Papalia, 2013). Melalui keanekaragaman, dapat diketahui jumlah jenis makroalga yang hidup di sutau perairan. Jumlah jenis sangat mempengaruhi nilai keanekaragaman. Semakin banyak jumlah jenis makroalga, maka semakin tinggi nilai keanekaragamannya (Arfah \& Patty, 2014). Haya merupakan salah satu desa di Kabupaten Maluku Tengah yang memiliki keanekaragaman jenis makroalga tersebar pada pantai dengan berbagai habitat dan belum teridentifikasi jenis dan sebarannya pada ekosistem lamun dan terumbu karang. Selain itu juga, keberadaan makroalga terancam oleh berbagai macam aktifitas masyarakat seperti pembuangan sampah dan limbah rumah tangga ke pantai, serta aktivitas nelayan menggunakan perahu yang merusak habitat makroalga.

Hasil penelitian Ariani dkk., (2017) terkait distribusi makroalga di perairan Desa Lalowaru diperoleh pola distribusinya secara mengelompok dan seragam berdasarkan tipe substrat. Selanjutnya hasil penelitian Farito dkk., (2018) di perairan Desa Tanjung Tiram diperoleh nilai keanekaragaman jenis makroalga pada terumbu karang buatan dari sampah plastik berkisar antara 1,26-1,37 sehingga tergolong rendah. Penelitian yang memadukan distribusi dan keanekaragaman jenis makroalga pada ekosistem lamun dan terumbu karang belum pernah dilakukan. Maka dari itu diperlukan penelitian distribusi dan keanekaragaman jenis makroalga pada ekosistem lamun dan terumbu karang di pantai Desa Haya. Inti dari penelitian ini adalah mengetahui jumlah jenis makroalga yang melekatkan diri pada susbtrat di ekosistem lamun dan terumbu karang. Hal ini dikarenakan jumlah jenis makroalga sangat mempengaruhi nilai keanekaragaman dan cara melekatkan diri pada substrat berhubungan dengan distribusi.

\section{MATERI DAN METODE}

\section{Tempat dan waktu penelitian}

Penelitian ini dilaksanakan di pantai Desa Haya Kecamatan Tehoru Kabupaten Maluku Tengah (Gambar 1) pada bulan Juni-Juli 2020. 


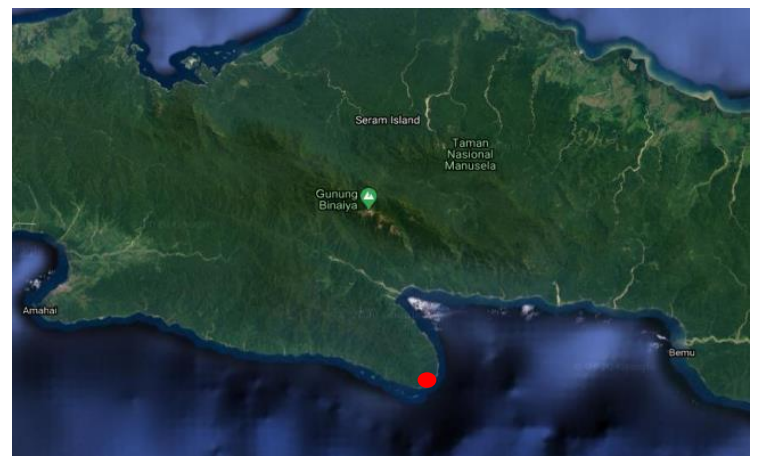

(a)

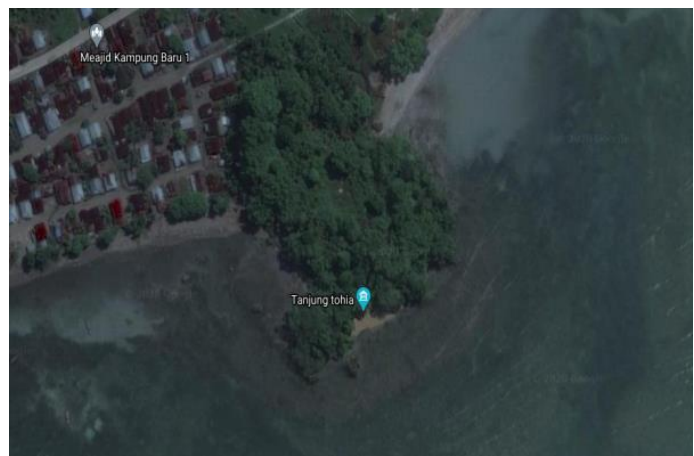

(b)

Gambar 1.Lokasi penelitian (a) Pulau Maluku; dan (b) Pantai Desa Haya Kabupaten Maluku Tengah

\section{Bahan dan alat}

Alat yang digunakan dalam penelitian ini adalah pipa paralon PVC $1 / 2$ inch untuk membuat kuadrat, tali nilon untuk membuat transek, meteran tancap 100 meter untuk mengukur jarak antar transek dan kuadrat, thermometer untuk mengukur suhu, bola arus untuk mengukur kuat arus, tongkat berskala untuk mengukur kedalaman, refaktometer untuk mengukur salinitas, dan $\mathrm{pH}$ meter untuk mengukur $\mathrm{pH}$, Adapun bahan yang digunakan adalah formaldehida $4 \%$ untuk mengawetkan sampel jenis makroalga.

\section{Metode}

\section{Pengumpulan data makroalga}

Pengumpulan data makroalga berdasarkan rona habitatnya yaitu pada ekosistem lamun dan terumbu karang. Tranek dibuat sebanyak 5 buah dengan panjang 100 meter dan jarak antartransek 25 meter. Pada masing-masing transek diletakan kuadrat dengan ukuran 1x1 meter sebanyak 10 buah dengan jarak antarkuadrat 10. Makroalga yang terdapat dalam setiap kuadrat diidentifikasi habitat dan dihitung jumlah jenisnya. Data identifikasi habitat akan digunakan untu mengetahui distribusi, sedangkan data jumlah jenis akan digunakan untuk menghitung nilai keanekaragaman.

\section{Pengumpulan data faktor lingkungan perairan}

Faktor lingkungan yang diukur adalah faktor fisika perairan berupa suhu menggunakan termometer, kuat arus menggunaan bola arus, dan kedalaman menggunakan tongkat berskala. Adapun faktor kimia perairan yang diukur berupa salinitas menggunakan refaktometer dan $\mathrm{pH}$ menggunakan $\mathrm{pH}$ meter.

\section{Identifikasi makroalga}

Jenis makroalga yang ditemukan pada ekosistem lamun dan terumbu karang diidentifikasi menggunakan acuan menurut Bhavanath et al., (2009).

\section{Analisis data}

Analisis distribusi habitat dilakukan berdasarkan hasil pengamatan makroalga pada ekosistem lamun dan terumbu karang, kemudian dibuat hasil dalam bentuk tabel. Adapun nilai keanekaragaman makroalga dihitung dengan menggunakan indeks diversitas menurut Shannon-Wiener yaitu:

$$
H^{\prime}=-\left(\sum P i \ln P i\right) \operatorname{dimana} P i=n i / N
$$

Keterangan: $H$ ' adalah indeks keanekaragaman, $P i$ adalah probalitas jenis ke-i, $n i$ adalah jumlah individu jenis ke-i, $N$ adalah jumlah total individu, $\ln$ adalah logaritma nature.

Dengan kriteria keanekaragaman jenis sebagai berikut: jika $H^{\prime}>3,3$, maka keanekaragaman jenis tinggi; jika 2,3< $H^{\prime}<3,3$, maka keanekaragaman jenis sedang; dan jika $H^{\prime}<2,3$, maka keanekaragaman jenis rendah.

\section{HASIL}

Jenis-jenis makroalga yang ditemukan pada ekosistem lamun dan terumbu karang di pantai Desa Haya. 
Berdasarkan hasil penelitian yang dilakukan pada setiap petak pengamatan di ekosistem lamun, diperoleh jenis-jenis makroalga yang dapat dilihat pada Tabel 1 . Tabel 1 menunjukan bahwa jenis makroalga yang ditemukan pada ekosistem lamun di pantai desa Haya sebanyak 5 jenis, dimana 1 jenis dari kelas Chlorophyceae, 2 jenis dari kelas Phaeophyceae, dan 2 jenis dari kelas Rhodophyceae.
Jenis-jenis makroalga yang ditemukan pada ekosistem terumbu karang di pantai Desa Haya dapat dilihat pada Tabel 2. Jenis makroalga yang ditemukan pada ekosistem lamun di pantai desa Haya sebanyak 7 jenis, dimana 1 jenis dari kelas Chlorophyceae, 1 jenis dari kelas Phaeophyceae, dan 5 jenis dari kelas Rhodophyceae.

Tabel 1. Jenis-jenis makroalga yang ditemukan pada ekosistem lamun di pantai Desa Haya.

\begin{tabular}{cll}
\hline No & \multicolumn{1}{c}{ Kelas } & \multicolumn{1}{c}{ Jenis } \\
\hline 1. & Chlorophyceae & Caulerpa serrulata (Forsskål) J. Agardh \\
2. & Phaeophyceae & Dictyopteris acrostichoides (J. Agardh) Bornet \\
3. & & Padina australis Hauck \\
4. & Rhodophyceae & Hypnea valentiae (Turner) Montagne \\
5. & & Liagora viscida (Forsskål) C. Agardh \\
\hline
\end{tabular}

Tabel 2. Jenis-jenis makroalga yang ditemukan pada ekosistem terumbu karang di pantai Desa Haya.

\begin{tabular}{ccl}
\hline No & Kelas & \multicolumn{1}{c}{ Jenis } \\
\hline 1. & Chlorophyceae & Dictyosphaeria cavernosa (Forsskål) Børgesen \\
2. & Phaeophyceae & Sargassum cincitum J. Agardh \\
3. & Rhodophyceae & Acantophora specivera $($ Vahl) Børgesen \\
4. & Gracilaria corticata J. Agardh \\
5. & Gracilaria dura $($ C. Agardh) J. Agardh \\
6. & Gracilaria salicornia $($ C. Agardh) Dawson \\
7. & Laurensia papilosa (C. Agardh) Greville \\
\hline
\end{tabular}

\section{Distribusi makroalga pada ekosistem lamun dan terumbu karang di pantai Desa Haya.}

Berdasarkan hasil penelitian yang dilakukan pada setiap petak pengamatan di ekosistem lamun dan terumbu karang, diperoleh distribusi makroalga yang dapat dilihat pada Tabel 3. Tabel 3 menunjukan bahwa distribusi makroalga pada ekosistem lamun sebanyak 5 jenis, yaitu $C$. serrulata, D. acrostichoides, $P$. australis, $H$. valentiae dan L. viscida. Distribusi makroalga pada ekosistem lamun dengan cara melekat pada pasir dan lumpur. Adapun distribusi makroalga pada ekosistem terumbu karang sebanyak 7 jenis, yaitu $D$. cavernosa, $S$. cinicitum, A. specivera, $G$. corticata, G. dura, G. salicornia, dan L. papilosa.
Distrubusi makroalga pada ekosistem terumbu karang dilakukan dengan cara melekat dan menancap pada batu karang.

\section{Keanekaragaman jenis makroalga pada ekosistem lamun dan terumbu karang di pantai Desa Haya.}

Nilai keanekaragaman jenis makroalga pada ekosistem lamun dan terumbu karang di pantai Desa Haya dapat dilihat pada Gambar 1 yang menunjukan bahwa nilai keanekaragaman jenis makroalga pada ekosistem lamun sebesar 1,381 sedangkan pada ekosistem terumbu karang sebesar 2,806. 
Tabel 3. Distribusi makroalga pada ekosistem lamun dan terumbu karang di pantai Desa Haya.

\begin{tabular}{|c|c|c|c|c|}
\hline \multirow[b]{2}{*}{ No } & \multirow[b]{2}{*}{ Jenis } & \multicolumn{2}{|c|}{ Ekosistem } & \multirow[b]{2}{*}{ Distribusi Habitat } \\
\hline & & Lamun & $\begin{array}{c}\text { Terumbu } \\
\text { Karang }\end{array}$ & \\
\hline 1. & C. serrulata & $\sqrt{ }$ & - & Melekat pada pasir di padang lamun \\
\hline 2. & D. cavernosa & - & $\sqrt{ }$ & Melekat pada pecahan karang di rataan terumbu \\
\hline 3. & D. acrostichoides & $\sqrt{ }$ & - & Melekat pada pasir di padang lamun \\
\hline 4. & P. australis & $\sqrt{ }$ & - & Melekat pada pasir di padang lamun \\
\hline 5. & S. cincitum & - & $\sqrt{ }$ & Menancap pada batu karang di rataan terumbu \\
\hline 6. & A. specivera & - & $\sqrt{ }$ & Melekat pada batu dipadang lamun \\
\hline 7. & G. corticata & - & $\sqrt{ }$ & Melekat pada batu karang di rataan terumbu \\
\hline 8. & G. dura & - & $\sqrt{ }$ & Melekat pada batu karang di rataan terumbu \\
\hline 9. & G. salicornia & - & $\sqrt{ }$ & Melekat pada batu karang di rataan terumbu \\
\hline 10. & H. valentiae & $\sqrt{ }$ & - & Melekat pada pasir di padang lamun \\
\hline 11. & L. papilosa & - & $\sqrt{ }$ & Melekat pada batu karang di rataan terumbu \\
\hline 12. & L. viscida & $\sqrt{ }$ & - & Melekat pada pasir di padang lamun \\
\hline
\end{tabular}

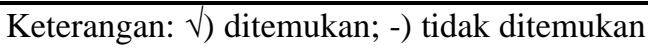

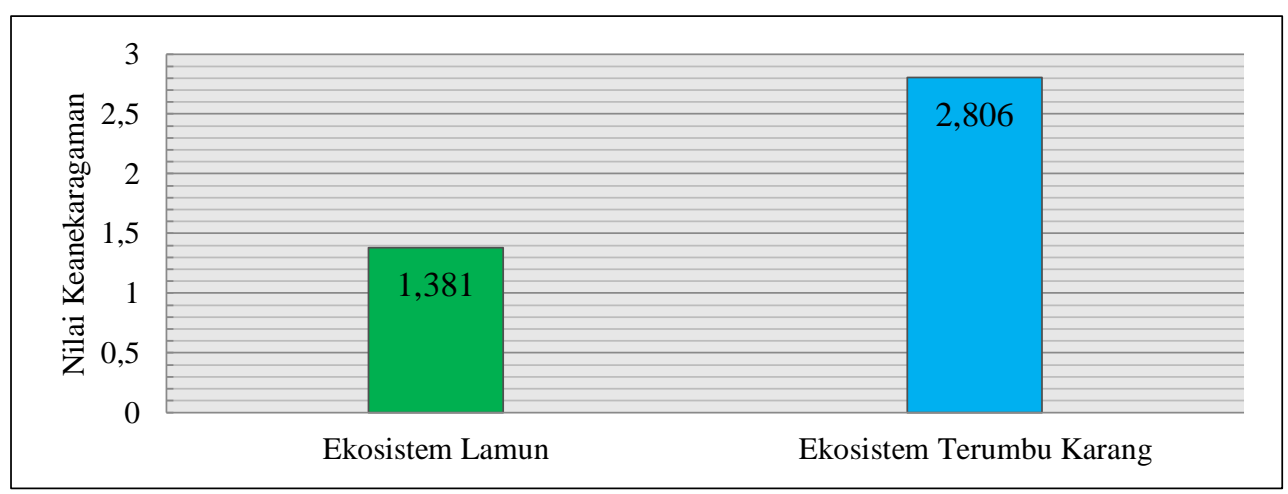

Gambar 1. Nilai keanekaragaman jenis makroalga pada ekosistem lamun dan terumbu karang di pantai Desa Haya.

\section{Kondisi faktor fisika kimia perairan di pantai Desa Haya.}

Kondisi faktor fisika kimia perairan (suhu, kecepatan arus, kedalaman, salinitas, dan $\mathrm{pH}$ ) pada ekosistem lamun dan terumbu karang di pantai Desa Haya dapat dilihat pada Tabel 4.
Rerata suhu air laut sebesar $29,2^{\circ} \mathrm{C}$, rerata kecepatan arus air laut sebesar $23,8 \mathrm{~cm} /$ detik, rerata kedalaman air laut sebesar $124 \mathrm{~cm}$, rerata salinitas air laut sebesar $32,9 \mathrm{ppt}$, dan rerata $\mathrm{pH}$ air laut sebesar 6,07.

Tabel 4. Kondisi faktor fisika kimia perairan di pantai Desa Haya Kabupaten Maluku Tengah.

\begin{tabular}{llllll}
\hline Ekosistem & $\begin{array}{l}\text { Suhu } \\
\left({ }^{\circ} \mathbf{C}\right)\end{array}$ & $\begin{array}{l}\text { Kuat arus } \\
(\mathbf{c m} / \text { detik })\end{array}$ & $\begin{array}{l}\text { Kedalaman } \\
(\mathbf{c m})\end{array}$ & $\begin{array}{l}\text { Salinitas } \\
(\mathbf{p p t})\end{array}$ & $\mathbf{p H}$ \\
\hline Lamun & 28,9 & 22,8 & 111,9 & 32,8 & 6,35
\end{tabular}




\begin{tabular}{llllll} 
Terumbu karang & 29,6 & 24,8 & 136,1 & 33,1 & 5,79 \\
\hline Rerata & 29,2 & 23,8 & 124 & 32,9 & 6,07 \\
\hline
\end{tabular}

\section{PEMBAHASAN}

\section{Jenis-jenis makroalga yang ditemukan pada ekosistem lamun dan terumbu karang di pantai Desa Haya Kabupaten Maluku Tengah.}

Berdasarkan hasil penelitian, makroalga yang ditemukan pada ekosistem lamun dan terumbu karang sebanyak 12 jenis. Adapun 5 jenis ditemukan pada ekosistem lamun dan 7 jenis pada ekosistem terumbu karang. Secara keseluruhan, jenis yang ditemukan tersebut dikelompokan dalam 3 kelas makroalga yaitu Chlorophyceae (makroalga hijau), Phaeophyceae (makroalga coklat), dan Rhodophyceae (makroalga merah).

Banyaknya jumlah jenis makroalga dari kelas Rhodophyceae pada ekosistem lamun dan terumbu karang di pantai Desa Haya dikarenakan kondisi fisika kimia perairan berupa suhu $\left(29,2^{\circ} \mathrm{C}\right)$, salinitas $(32,9 \mathrm{ppt})$ dan $\mathrm{pH}(6.07)$ pada ekosistem lamun dan terumbu karang di pantai Desa Haya masih berada dalam kisaran yang optimum. Hal ini didukung oleh Kadi (2017) yang menjelaskan bahwa suhu optimum untuk makroalga merah adalah $28-31^{\circ} \mathrm{C}$, salinitas optimum untuk makroalga merah adalah 28-32 ppt, dan $\mathrm{pH}$ optimum untuk makroalga merah adalah 6-8,5. Selain itu juga, banyaknya jumlah jenis makroalga dari kelas Rhodophyceae pada ekosistem lamun dan terumbu karang di pantai desa Haya dikarenakan jenis dari kelas Rhodophyceae dapat beradaptasi terhadap perubahan kondisi lingkungan yang diakibatkan oleh aktivitas masyarakat yang menyebabkan air laut menjadi asam. Hal ini didukung oleh Irwandi dkk., (2017) yang menyatakan bahwa jenis dari kelas makroalga merah memiliki kemampuan adaptasi yang lebih luas daripada kelas makroalga hijau dan coklat sehingga memiliki jumlah yang lebih banyak tersebar di perairan.

\section{Distribusi makroalga pada ekosistem lamun dan terumbu karang di pantai Desa Haya Kabupaten Maluku Tengah}

Berdasarkan hasil penelitian, distribusi makroalga pada ekosistem lamun dengan cara melekat pada substrat berupa pasir dan batu. Adapun, distribusi makroalga pada ekosistem terumbu karang dengan cara melekat dan menancap pada substrat batu karang. Melsasail (2016) menyatakan bahwa, substrat yang cocok bagi kehidupan makroalga berupa pasir, batu, pecahan karang, batu karang, dan tumbuhan laut yang lain (lamun).

Distribusi makroalga pada ekosistem terumbu karang dilakukan dengan cara melekat dan menancapkan holdfastnya pada batu karang. Hal tersebut dilakukan adar tidak terlepas ketika terkena hempasan ombak (Palallo, 2013). Ditambahkan juga oleh Irwandi dkk., (2017) bahwa makroalga yang biasanya hidup pada terumbu karang berasal dari genus Sargassum, Turbinaria, Ulva, Gracilaria, Laurensia, Acantophora, Dictyosphaeria, dan sebagainya.

Distribusi makroalga pada ekosistem lamun dilakukan dengan cara melekat pada lamun (berasosiasi), pasir, batu, dan benda-benda keras yang secara kebetulan tenggelam (Riniatsih dkk., 2017). Menurut Putra dkk., (2019), distribusi makroalga pada ekosistem lamun tergantung pada ombak. Hal ini dikarenakan terbatasnya bendabenda keras pada ekosistem lamun untuk makroalga melekatkan holdfastnya. Ditambahkan juga oleh Irwandi dkk., (2017) bahwa makroalga yang hidup pada substrat pasir berasal dari genus Caulerpa, Amphiroa, Padina, Dictyopteris, Hypnea, Liagora, dan sebagainya.

Jenis substrat merupakan indikator utama bagi distribusi makroalga di suatu perairan. Substrat dasar pantai Desa Haya berupa pasir, batu, pecahan karang, dan karang mati. Makroalga 
yang hidup pada substrat berupa pasir dan lumpur memiliki holdfast berbentuk umbi sehingga dapat mengikat partikel-partikel pasir. Selain itu, makroalga yang hidup pada substrat berupa batu, pecahan karang, karang mati memiliki holdfast berbentuk bercabang-cabang atau cakram (Melsasail, 2016). Penelitian yang dilakukan oleh Palallo (2013) di Pulau Bonebatang yang menemukan bahwa distribusi makroalga pada ekosistem lamun sebanyak 8 jenis dengan cara melekat dan menempel pada pasir, batu, lamun, dan makroalga yang lain. Adapun distribusi makroalga pada ekosistem terumbu karang sebanyak 8 jenis dengan cara melekat dan menancap batu karang di rataan terumbu.

\section{Keanekaragaman jenis makroalga pada ekosistem lamun dan terumbu karang di pantai Desa Haya Kabupaten Maluku Tengah.}

Berdasarkan hasil perhitungan, nilai keanekaragaman jenis makroalga pada ekosistem lamun sebesar 1,381 dengan jumlah jenis 5 dan jumlah total individu 249. Adapun nilai keanekaragaman jenis makroalga pada ekosistem terumbu karang sebesar 2,806 dengan jumlah jenis 7 dan jumlah total individu 376.

Melsasail (2016) menjelaskan bahwa jika $H^{\prime}>3,3$, maka keanekaragaman jenis tinggi; jika 2,3< $H^{\prime}<3,3$, maka keanekaragaman jenis sedang; dan jika $H^{\prime}<2,3$, maka keanekaragaman jenis rendah. Berdasarkan kriteria tersebut dapat disimpulkan bahwa keanekaragaman jenis makroalga pada ekosistem terumbu karang tergolong sedang $(2,806)$. Adapun keanekaragaman jenis makroalga pada ekosistem lamun tergolong rendah $(1,381)$.

Nilai keanekaragaman jenis makroalga pada stasiun ekosistem terumbu karang tergolong sedang dikarenakan pada ekosistem terumbu karang didominasi oleh substrat keras seperti batu dan batu karang, dimana substrat tersebut sangat diperlukan oleh makroalga untuk menancapkan dan melekatkan diri agar tidak terlepas saat dihempas arus, dan terlindung dari ombak yang kuat. Hal ini sesuai dengan pendapat Nyabakken (1992) yang menjelaskan bahwa substrat berbatu pada daerah intertidal merupakan daerah yang paling padat organismenya dan mempunyai keanekaragaman terbesar baik untuk spesies hewan maupun tumbuhan, sedangkan untuk substrat berpasir keragamannya sedikit.

Nilai keanekaragaman jenis makroalga pada ekosistem lamun tergolong rendah dikarenakan memiliki substrat berupa pasir, dan lumpur. Hal ini menyebabkan terbatasnya substrat keras untuk makroalga melekat dan menancapkan diri, sehingga pada saat terjadi ombak besar banyak ditemukan makro alga yang terlepas dan terdampar di sepanjang tepi pantai. Hal ini sesuai dengan pendapat Melsasail (2016) yang menjelaskan bahwa di perairan yang memiliki substrat pasir dan lumpur, makroalga biasanya ditemukan dalam jumlah yang sedikit karena terbatasnya benda-benda keras yang cukup kokoh dan kuat untuk dijadikan sebagai tempat melekatkan diri.

Menurut Liline (2010), tinggi rendahnya nilai keanekaragaman dipengaruhi oleh jumlah jenis. Semakin banyak jumlah jenis maka nilai keanekaragamannya tinggi, sebaliknya semakin sedikit jumlah jenis maka nilai keankearagamannya rendah. Hal ini didukung oleh penelitian yang dilakukan oleh Irwandi dkk., (2017) di perairan desa Tanjung Tiram yang menemukan bahwa makroalga yang ditemukan pada substrat berupa pecahan karang sebanyak 12 jenis sehingga nilai keanekaragamannya lebih tinggi dibandingkan dengan makroalga yang ditemukan substrat berupa pasir karena hanya memiliki 5 jenis.

\section{Kondisi faktor fisika kimia perairan di pantai Desa Haya.}

Rata-rata suhu air laut yang ada pada perairan pantai desa Haya adalah $29,2^{\circ} \mathrm{C}$. Rata-rata suhu tersebut masih berada dalam kisaran optimum untuk pertumbuhan makroalga. Hal ini dikarenakan menurut Armita (2011), kisaran suhu yang baik bagi pertumbuhan makroalga adalah 26-33 ${ }^{\circ} \mathrm{C}$. Rata-rata kuat arus air laut yang ada pada perairan pantai desa Haya adalah 23,8 $\mathrm{cm} /$ detik. Rata-rata kuat arus tersebut masih berada dalam kisaran optimum untuk 
pertumbuhan makroalga. Kisaran kuat arus air laut yang baik untuk pertumbuhan makroalga adalah 20-40 cm/detik (Palallo, 2013). Rata-rata kedalaman air laut yang ada pada perairan pantai desa Haya adalah $124 \mathrm{~cm}$. Rata-rata kedalaman air laut tersebut masih berada dalam kisaran optimum untuk pertumbuhan makroalga. Hal ini dikarenakan menurut Palallo (2013), makroalga dapat dijumpai pada kisaran kedalaman 0-15 meter. Rata-rata salinitas air laut yang ada pada perairan pantai desa Haya adalah 32,9 ppt. Ratarata salinitas air laut tersebut masih berada dalam kisaran optimum untuk pertumbuhan makroalga. Kisaran salinitas yang baik bagi pertumbuhan makroalga adalah 32-34 ppt (Armita, 2011). Ratarata $\mathrm{pH}$ air laut yang ada di perairan pantai desa Haya adalah 6,07. Rata-rata $\mathrm{pH}$ tersebut tidak baik bagi pertumbuhan makroalga. Hal ini dikarenakan menurut Armita (2011), kisaran pH yang baik bagi pertumbuhan makroalga adalah $\mathrm{pH}$ netral (7) sampai basa (9).

Penyebab kondisi $\mathrm{pH}$ air laut menjadi tidak bagi pertumbuhan makroalga karena kondisi perairan yang tidak bersih. Hal ini ditunjukan dengan banyaknya sampah bertebaran di tepi pantai sehingga menyebabkan air laut menjadi asam (Tabel 4). Hal ini sesuai dengan pernyataan Armita (2011) bahwa perubahan $\mathrm{pH}$ air laut menjadi asam disebabkan pertambahan bahanbahan organik yang kemudian membebaskan $\mathrm{CO}_{2}$ jika mengurai.

Penelitian ini terbatas pada distribusi dan keanekaragaman jenis makroalga. Selain itu juga, faktor fisika kimia perairan yang diukur hanya berupa suhu, kecepatan arus, salinitas, dan $\mathrm{pH}$ air laut. Perlu adanya penelitian selanjutnya yang mangkaji tentang struktur komunitas dan pola distrubusi makroalga pada ekosistem lamun dan terumbu karang di pantai Desa Haya. Selain itu juga, faktor fisika kimia yang perlu diukur lagi berupa kecerahan, Biological Oxygen Demand (BOD), Chemical Oxygen Demand (COD), nitrat, dan fosfat air laut. Hasil dari penelitian ini sangat penting karena dapat memberikan informasi kepada Lembaga Lingkungan Hidup, Dinas Perikanan, dan masyarakat tentang distribusi dan keanekaragaman jenis makroalga pada ekosistem lamun dan terumbu karang serta menentukan langkah pengelolaan untuk mengurangi pengrusakan wilayah pesisir di Desa Haya.

\section{SIMPULAN}

Makroalga yang ditemukan di pantai desa Haya sebanyak 12 jenis, dimana 5 jenis yaitu $C$. serrulata, D. acrostichoides, $P$. australis, $H$. valentiae, dan L. viscida pada ekosistem lamun dan 7 jenis yaitu D. cavernosa, S. cincitum, A. specivera, G. corticata, G. dura, G. salicornia, dan L. papilosa pada ekosistem terumbu karang. Distribusi makroalga pada ekosistem lamun dengan cara melekat pada substrat pasir dan lumpur, sedangkan pada terumbu karang dengan cara melekat dan menancap pada batu karang di rataan terumbu. Nilai keanekaragaman jenis makroalga pada ekosistem lamun tergolong rendah, sedangkan pada terumbu karang tergolong sedang. Kodisi faktor fisika-kimia perairan berupa suhu, kuat arus, kedalaman, dan salinitas air laut masih berada dalam kisaran yang baik untuk pertumbuhan makroalga, sedangkan $\mathrm{pH}$ air laut berada dalam kisaran yang tidak baik.

\section{UCAPAN TERIMA KASIH}

Penulis mengucapkan terima kasih kepada Direktorat Riset dan Pengabdian Masyarakat Direktorat Jenderal Riset dan Pengembangan Kementrian Riset, Teknologi, dan Perguruan Tinggi sebagai penyandang dana untuk penelitian.

\section{KEPUSTAKAAN}

Arfah H, Patty SI. 2014. Keanekaragaman dan Biomassa Makroalga di Perairan Pantai Teluk Kotania Seram Barat. Jurnal Ilmiah Platax 2(2). E-ISSN 2302-3689.

Armita D. 2011. Analisis Perbandingan Kualitas Air di Daerah Budidaya Rumput Laut dengan di Dusun Malelaya Desa Punaga Kecamatan Mangarabombang Kabupaten Takalar. Skripsi FIKP. Universitas Hasanuddin. 62 hlm. 
Ariani, Nurgayah W, Afu LOA. 2017. Komposisi dan distribusi makroalga verdasarkan tipe substrat di perairan Desa Lalouaru Kecamatan Moramo Utara. Jurnal Sapa Laut 2(1): 25-30. E-ISSN 2503-0396.

Ayhuan HV, Zamani NP, Soedharma D. 2017. Analisis struktur komunitas makroalga ekonomis penting di perairan intertidal Manokwari Papua Barat. Jurnal Teknologi Perikanan dan Kelautan 8(1): 19-38.

Bhavanath J, Reddy CRK, Thakur MC, Rao MU. 2009. The diversity and distribution of seaweed of the Gujarat Coast. 232p.

Irwandi, Salwiyah, Nurgayah W. 2017. Struktur Komunitas makroalga pasa substrat yang berbeda di perairan Desa Tanjung Tiram Kecamatan Moramo Utara Kabupaten Konawe Selatan Provinsi Sulawesi Tenggara. Jurnal Manajemen Sumber Daya Perairan 2(3): 215-224.

Farito, Kasim M, Nur AI. 2018. Studi Kepadatan dan Keanekaragaman makroalga pada terumbu karang buatan dari sampah plastik di perairan Desa Tanjung Tiram Kecamatan Moramo Utara Kabuaten Konawe Selatan. Jurnal Manajemen Sumber Daya Perairan 3(2): 93-103.

Kadi A. 2017. Interaksi komunitas makroalga dengan lingkungan perairan Teluk Carita Pandeglang. Biosfera 34(1):32-38.

Krupek RA, Branco CZ. 2012. Ecological Distribution of Stream Macroalgae in different spatial scales using taxonomic and morphological groups. Brazilian Journal of Botany 35(3):273-280.

Liline S. 2010. Komunitas rumput laut (seaweed) di perairan pantai Dusun Pulau Osi Desa Eti Kabupaten Seram Bagian Barat sebagai materi pembelajaran muatan lokal di Sekolah Menengah Atas. Tesis tidak diterbitkan. Malang: Program Pascasarjana Universitas Negeri Malang.

Litaay C. 2014. Sebaran dan keragaman komunitas makroalga di perairan Teluk Ambon. Jurnal Ilmu dan Teknologi Kelautan Tropis 6(1):131-142.
Melsasail K, Awan A, Papilaya MP. 2018. Analysis of environmental physical-chemical factors and macroalga species in the coastal water of Nusalaut, Central Maluku Indonesia. Sriwijaya Journal of Environment 3(1): 31-36.

Nurmiyati. 2013. Keragaman, distribusi dan nilai penting makroalga di pantai Sepanjang Gunung Kidul. Jurnal Bioedukasi 6(1):1221.

Nybakken JW. 1992. Biologi Laut Suatu Pendekatan Ekologis. Gramedia: Jakarta.

Palallo A. 2013. Distribusi Makroalga pada Ekosistem Lamun dan Terumbu Karang di Pulau Bonebatang, Kecamatan Ujung Tanah, Kelurahan lompo, Makassar. Skripsi FKIP.UNHAS. $68 \mathrm{hlm}$.

Papalia S. 2013. Studi distribusi dan keragaman jenis makroalga di perairan Desa Kayeli dan Jikumerasa Pulau Buru, Provinsi Maluku. Prosiding FMIPA Universitas Pattimura ISBN: 978-602-97522-0-5.

Putra RAW, Santoso A, Riniatsih I. 2019. Kelimpahan rumput laut di komunitas lamun di perairan Pulau Nyamuk Kepulauan Karimunjawa. Journal of Marine Research 8(1):75-84.

Riniatsih I, Munasik M, Suryono CA, Azizah R, Hartati R, Pribadi R, Subagiyo S. 2017. Komposisi makroalga yang berasosiasi di ekosistem padang lamun Pulau Tumpul Lunik, Pulau Rimau Balak Dan Pulau Kandang Balak Selatan, Perairan Lampung Selatan. Jurnal Kelautan Tropis 20(2):117123.

Soegiarto A, Sulistijo, Vanda SA. 2011. Rumput Laut (Algae). Manfaat, Potensi dan Usaha Budidaya. Penerbit Lembaga Oseanologi Nasional (LON-LIPI). Jakarta. 